\title{
Neurocognitive impairment after off-pump and on-pump coronary artery bypass graft surgery - an Iranian experience
}

This article was published in the following Dove Press journal:

Neuropsychiatric Disease and Treatment

18 November 2010

Number of times this article has been viewed

\section{Mehdi Farhoudi' \\ Kaveh Mehrvar ${ }^{2}$ \\ Abbas Afrasiabi ${ }^{3}$ \\ Rezayat Parvizi ${ }^{3}$ \\ Ahmad Ali Khalili ${ }^{3}$ \\ Babak Nasiri ${ }^{3}$ \\ Khosrow Hashemzadeh ${ }^{3}$ \\ Kamyar Ghabili ${ }^{4}$}

'Neurosciences Research Center, Imam Reza Hospital, ${ }^{2}$ Razi Hospital,

${ }^{3}$ Cardiovascular Research Center,

${ }^{4}$ Tuberculosis and Lung Disease

Research Center, Tabriz University of

Medical Sciences, Tabriz, Iran
Correspondence: Kamyar Ghabili Tuberculosis and Lung Disease Research Center, Tabriz University of Medical

Sciences, Tabriz, Iran

$\mathrm{Tel}+989144106136$

Fax +984|| 336|| 20$

Email kghabili@gmail.com
Background: Coronary artery bypass graft (CABG) surgery is one of the most commonly performed surgical procedures worldwide, and it may be accompanied by postoperative neurocognitive impairment. Although this complication has been attributed to the use of cardiopulmonary bypass, it is still a matter of debate whether the switch from on-pump to off-pump technique affects the cognitive function.

Objective: The aim of this study was to compare the impact of the on-pump and off-pump techniques on neurocognitive impairment in low-risk CABG surgery groups.

Methods: In a descriptive and analytic study, $201 \mathrm{CABG}$ patients with left-ventricular ejection fraction $>30 \%$, and without cardiac arrhythmia were enrolled. Before the elective operation, all patients underwent neurological examination and neurocognitive test, Mini-Mental State Examination (MMSE). Two months following the operation, both on- and off-pump, the patients were re-examined by MMSE to detect any neurocognitive impairment.

Results: Out of 154 patients included in the study, 95 (61.6\%) and $59(38.3 \%)$ patients were in off-pump and on-pump groups, respectively. Mean age of the patients was $57.17 \pm 9.82$ years. A 2-month postoperative neurocognitive impairment was detected among 17 patients of on-pump group (28.8\%) and in 28 cases of off-pump group $(29.4 \%)(P=0.54)$. The mean postoperative MMSE scores were not comparable between groups (25.01 \pm 4.49 in off-pump group versus $23.73 \pm 4.88$ in on-pump group, $P=0.09$ ).

Conclusion: The present study revealed that in low-risk patients undergoing CABG surgery, either the techniques of on-pump or off-pump did not differ regarding the neurocognitive outcome 2 months after the procedure.

Keywords: neurocognitive impairment, off-pump, on-pump, coronary artery bypass graft surgery

\section{Introduction}

Coronary artery bypass graft (CABG) surgery is one of the most commonly performed surgical procedures worldwide, intended to treat ischemic heart disease and alleviate angina pectoris. ${ }^{1-3}$ Despite advances in the surgical procedure, neurological injury is still an important complication after CABG surgery and is found in two types. ${ }^{4}$ The first type of neurological injury occurs in 3\%-6\% of the cases with manifestations such as stroke, transient ischemic attack, and coma. On the other hand, impairment of cognitive function including defects of attention, concentration, short-term memory, fine motor function, and speed of mental and motor responses is found in the milder type second, ${ }^{4,5}$ With an incidence of $20 \%-80 \%$, neurocognitive impairment after cardiac surgery has been largely attributed to the use of cardiopulmonary bypass (CPB). ${ }^{6-9}$ 
CPB increases the permeability of the blood-brain barrier and generates microemboli, which may affect cognitive function. ${ }^{10,11}$ Recently, cardiac stabilizer devices have been developed to facilitate CABG without using CPB (off-pump CABG surgery). Although diminished cerebral embolism in off-pump CABG has been highlighted, ${ }^{12}$ it is still controversial whether the switch from on-pump to off-pump technique fully alleviates the cognitive dysfunction. Minor improvements in cognitive function shortly after operation, ${ }^{4,12,13}$ better cognitive outcome, ${ }^{14,15}$ and no improvement in neurocognitive status after off-pump CABG have been hitherto reported in off-pump CABG in comparison to the on-pump method. ${ }^{16}$ Due to the aforementioned controversy, the present study was designed to compare the impact of the on-pump and off-pump techniques on neurocognitive impairment in lowrisk CABG groups.

\section{Methods}

In a descriptive, analytic, and prospective follow-up study, 201 candidates for CABG surgery were enrolled at Madani Heart Hospital in Tabriz, Iran. Inclusion criteria were elective $\mathrm{CABG}$, lack of concomitant cardiac arrhythmia, and left-ventricular ejection fraction $(\mathrm{LVEF})>30 \%$. Patients undergoing emergency $\mathrm{CABG}$ or $\mathrm{CABG}$ combined with other surgical procedures such as valve replacement or carotid endarterectomy and those with history of neurological and psychiatric diseases were excluded from the study. Before operation, all patients underwent neurological and neurocognitive (Mini-Mental State Examination, MMSE) examination.

Patients were assigned to on- or off-pump groups. CABG was carried out through median sternotomy. The anesthetic technique was standardized and all patients received the similar protocol. Follow-up study was performed up to
2 months after operation by neurological and neurocognitive examination. A decline of $\geq 1$ score in MMSE after surgery was defined as cognitive dysfunction. All data are presented as mean values \pm SD. Statistical analysis was performed with SPSS for Windows (version 13.0; SPSS Inc., Chicago, IL) using independent samples $t$-test, paired samples $t$-test, and chi-squared test, whenever appropriate. A $P$ value of less than 0.05 was considered to represent significant difference. The Research Vice-Chancellor of Tabriz Medical Faculty approved this study.

\section{Results}

Out of 201 patients enrolled in the study, 47 patients refused or were unable to return for follow-up. Data from 154 patients were therefore analyzed: $95(61.6 \%)$ in off-pump group and $59(38.3 \%)$ in on-pump group. Out of 154 patients, 123 $(79.8 \%)$ were male and $31(20.1 \%)$ were female. The mean age of patients was $57.17 \pm 9.82$ years ranging from $31-82$. Mean LVEF was $50.65 \pm 9.41 \%$. The patients' baseline characteristics are shown in Table 1.

There was no intraoperative accident. Two patients in on-pump group (2.5\%) and nine patients in off-pump group $(7.4 \%)$ had postoperative myocardial infarction $(P>0.05)$. In each group, there were two postoperative strokes. There was only one death in off-pump group; the cause was severe cardiac disease and postoperative cardiac arrest, and no neurological complication was found. In on-pump group, there was no significant difference between the mean preoperative and postoperative MMSE scores (23.24 \pm 5.03 versus $23.73 \pm 4.88, P=0.16)$. However, in off-pump group, the mean 2-month postoperative MMSE score was significantly higher than the mean preoperative MMSE score $(25.01 \pm 4.49$ versus $24.18 \pm 4.51, P=0.007)$. On the basis of the MMSE results, cognitive impairment was detected in

Table I Baseline participants' characteristics and pre- and postoperative MMSE scores $(n=20 \mathrm{I})$

\begin{tabular}{|c|c|c|c|}
\hline & Off-pump group $(n=95)$ & On-pump group $(n=59)$ & $P$ value \\
\hline Gender (male:female) & $77: 18$ & $46: 13$ & 0.391 \\
\hline Age (years) & $56.34 \pm 9.00$ & $58.51 \pm 10.97$ & $0.18^{2}$ \\
\hline Coronary vessel disease & - & - & $0.09^{\prime}$ \\
\hline I-vessel disease & $4(4.2 \%)$ & $0(0)$ & - \\
\hline 2-vessel disease & 34 (35.7\%) & 15 (25.4\%) & - \\
\hline$\geq 3$-vessel disease & $57(60 \%)$ & $43(72.8 \%)$ & - \\
\hline Diabetes mellitus & $24(25.2 \%)$ & 7 (I I.8\%) & $0.03^{1^{*}}$ \\
\hline History of hypertension & $40(42.1 \%)$ & $30(50.8 \%)$ & $0.21^{1}$ \\
\hline Preoperative MMSE score & $24.18 \pm 4.51$ & $23.24 \pm 5.03$ & $0.23^{2}$ \\
\hline Postoperative MMSE score & $25.01 \pm 4.49$ & $23.73 \pm 4.88$ & $0.09^{2}$ \\
\hline Postoperative neurocognitive impairment & $28(29.4 \%)$ & $17(28.8 \%)$ & $0.54^{\prime}$ \\
\hline
\end{tabular}

Notes: 'Chi-square test; ${ }^{2}$ Independent samples $t$-test. "Statistically significant $(P<0.05)$.

Abbreviation: MMSE, Mini-Mental State Examination. 
$21.2 \%$ of the cases in on-pump group and $23.1 \%$ in off-pump $(P=0.54$, Table 1$)$.

\section{Discussion}

The results of this study showed no significant difference in postoperative neurocognitive impairment between on-pump and off-pump low-risk CABG surgery groups. This is in agreement with the findings of some previous studies that failed to detect any difference in neurocognitive impairment between on- and off-pump techniques. ${ }^{16-20}$ Jensen et al recently found similar cognitive outcome 3 months after offpump and on-pump surgery in a group of elderly with high risk for CABG surgery. ${ }^{18}$ Interestingly, Ernest et al revealed no difference in neurocognitive state at 2 and 6 months following $\mathrm{CABG}$ surgery between both groups, with the exception that fewer off-pump patients showed impairment on verbal fluency at 6 months. ${ }^{20}$

In contrast to the findings of the present study, some investigations have demonstrated favorable results for patients who underwent off-pump CABG surgery. Murkin et $\mathrm{al}^{21}$ and Zamvar et al ${ }^{15}$ reported less neurocognitive impairment among off-pump patients at first week postoperatively, while Motallebzadeh et al found better neurocognitive function at discharge from hospital but no difference at 6 months postoperatively. ${ }^{4}$ Stroobant et al concluded contrarily, ie, no difference at discharge but better function at 6 months postoperatively for off-pump group. ${ }^{22}$ However, van Dijk et al showed that low-risk patients avoiding the use of CPB had no effect on 5-year cognitive outcomes. ${ }^{23}$ Altogether, such a matter of controversy in neurocognitive impairment between on- and off-pump CABG surgery has been attributed to the variations in the tests used, the time points of assessment, the definition of impairment, and the statistical methods used for comparing groups. ${ }^{4,24}$ On the other hand, factors other than CPB may be responsible for cognitive decline, such as anesthesia and the generalized inflammatory response that is associated with major surgical procedures. ${ }^{4,25}$

The present study has several limitations. First, assessment of neurocognitive function was done only by one neuropsychological test (MMSE) and $\geq 1$ score decline in MMSE was defined as cognitive impairment. Second, MMSE is a simple screening instrument which might not be reliable in detection of subtle cognitive impairment. Therefore, a more rigorous set of neuropsychological tests is required in further investigations. Third, MMSE scores were not corrected for educational attainment and age. This might explain quite low preoperative MMSE scores in the present study. ${ }^{26}$ Fourth, the results of this investigation cannot be extrapolated to older patients with more advanced coronary artery disease or higher preoperative risks. On the other hand, large sample size along with the follow-up rate of $76 \%$ which is comparable to the previous studies is among the advantages of the current study. $4,7,27$

On the basis of these findings, we conclude that in lowrisk patients undergoing $\mathrm{CABG}$ surgery, avoiding the use of CPB had no effect on cognitive outcome 2 months after the procedure.

\section{Acknowledgment}

This study was financially supported by a grant from the Research Vice-Chancellor office of Tabriz University of Medical Sciences.

\section{Disclosure}

The authors report no conflicts of interest in this work.

\section{References}

1. Yoon BW, Bae HJ, Kang DW, et al. Intracranial cerebral artery disease as a risk factor for central nervous system complications of coronary artery bypass graft surgery. Stroke. 2001;32:94-99.

2. Farhoudi M, Afrasiabi A, Tarzamni MK, Khoshnan M, Arami MA Transcranial and carotid Doppler study in coronary artery bypass graft patient. Neurosciences. 2004;9:186-189.

3. Farhoudi M, Parvizi R, Bilehjani E, Tarzamni MK, Mehrvar K, Safaiyan A. Preoperative transcranial and carotid Doppler study in coronary artery bypass graft patients. Neurosciences. 2007;12: $42-45$.

4. Motallebzadeh R, Bland JM, Markus HS, Kaski JC, Jahangiri M. Neurocognitive function and cerebral emboli: randomized study of on-pump versus off-pump coronary artery bypass surgery. Ann Thorac Surg. 2007;83:475-482.

5. Roach GW, Kanchuger M, Mangano CM, et al. Adverse cerebral outcomes after coronary bypass surgery. Multicenter Study of Perioperative Ischemia Research Group and the Ischemia Research and Education Foundation Investigators. N Engl J Med. 1996;335:1857-1863.

6. Vingerhoets G, van Nooten G, Vermassen F, de Soete G, Jannes C. Short-term and long-term neuropsychological consequences of cardiac surgery with extracorporeal circulation. Eur J Cardiothorac Surg. 1997;11:424-431.

7. van Dijk D, Jansen EW, Hijman R, et al. Cognitive outcome after offpump and on-pump coronary artery bypass graft surgery: a randomized trial. JAMA. 2002;287:1405-1412.

8. Newman MF, Mathew JP, Grocott HP, et al. Central nervous system injury associated with cardiac surgery. Lancet. 2006;368:694-703.

9. van Dijk D, Keizer AM, Diephuis JC, Durand C, Vos LJ, Hijman R. Neurocognitive dysfunction after coronary artery bypass surgery: a systematic review. J Thorac Cardiovasc Surg. 2000;120: 632-639.

10. Harris DN, Bailey SM, Smith PL, Taylor KM, Oatridge A, Bydder GM. Brain swelling in first hour after coronary artery bypass surgery. Lancet 1993;342:586-587.

11. Lund C, Hol PK, Lundblad R, et al. Comparison of cerebral embolization during off-pump and on-pump coronary artery bypass surgery. Ann Thorac Surg. 2003;76:765-770.

12. Bowles BJ, Lee JD, Dang CR, et al. Coronary artery bypass performed without the use of cardiopulmonary bypass is associated with reduced cerebral microemboli and improved clinical results. Chest. 2001;119:25-30. 
13. Lee JD, Lee SJ, Tsushima WT, et al. Benefits of off-pump bypass on neurologic and clinical morbidity: a prospective randomized trial. Ann Thorac Surg. 2003;76:18-25.

14. Diegeler A, Hirsch R, Schneider F, et al. Neuromonitoring and neurocognitive outcome in off-pump versus conventional coronary bypass operation. Ann Thorac Surg. 2000;69:1162-1166.

15. Zamvar V, Williams D, Hall J, et al. Assessment of neurocognitive impairment after off-pump and on-pump techniques for coronary artery bypass graft surgery: prospective randomised controlled trial. BMJ. 2002;325:1268.

16. Lloyd CT, Ascione R, Underwood MJ, Gardner F, Black A, Angelini GD. Serum S-100 protein release and neuropsychologic outcome during coronary revascularization on the beating heart: a prospective randomized study. J Thorac Cardiovasc Surg. 2000;119:148-154.

17. Lund C, Sundet K, Tennøe B, et al. Cerebral ischemic injury and cognitive impairment after off-pump and on-pump coronary artery bypass grafting surgery. Ann Thorac Surg. 2005;80:2126-2131.

18. Jensen BO, Hughes P, Rasmussen LS, Pedersen PU, Steinbrüchel DA. Cognitive outcomes in elderly high-risk patients after off-pump versus conventional coronary artery bypass grafting: a randomized trial. Circulation. 2006;113:2790-2795.

19. Vedin J, Nyman H, Ericsson A, Hylander S, Vaage J. Cognitive function after on or off pump coronary artery bypass grafting. Eur J Cardiothorac Surg. 2006;30:305-310.

20. Ernest CS, Worcester MU, Tatoulis J, et al. Neurocognitive outcomes in off-pump versus on-pump bypass surgery: a randomized controlled trial. Ann Thorac Surg. 2006;81:2105-2114.
21. Murkin JM, Newman SP, Stump DA, Blumenthal JA. Statement of consensus on assessment of neurobehavioral outcomes after cardiac surgery. Ann Thorac Surg. 1995;59:1289-1295.

22. Stroobant N, van Nooten G, Belleghem Y, Vingerhoets G. Short-term and long-term neurocognitive outcome in on-pump versus off-pump CABG. Eur J Cardiothorac Surg. 2002;22:559-564.

23. van Dijk D, Spoor M, Hijman R, et al. Cognitive and cardiac outcomes 5 years after off-pump vs on-pump coronary artery bypass graft surgery. JAMA. 2007;297:701-708.

24. Mahanna EP, Blumenthal JA, White WD, et al. Defining neuropsychological dysfunction after coronary artery bypass grafting. Ann Thorac Surg. 1996;61:1342-1347.

25. Moller JT, Cluitmans P, Rasmussen LS, et al; Long-term postoperative cognitive dysfunction in the elderly ISPOCD1study. ISPOCD investigators. International Study of Post-Operative Cognitive Dysfunction. Lancet. 1998;351:857-861.

26. Crum RM, Anthony JC, Bassett SS, Folstein MF. Population-based norms for the Mini-Mental State Examination by age and educational level. JAMA. 1993;269:2386-2391.

27. Newman MF, Kirchner JL, Phillips-Bute B, et al. Longitudinal assessment of neurocognitive function after coronary-artery bypass surgery. N Engl J Med. 2001;344:395-402.
Neuropsychiatric Disease and Treatment

\section{Publish your work in this journal}

Neuropsychiatric Disease and Treatment is an international, peerreviewed journal of clinical therapeutics and pharmacology focusing on concise rapid reporting of clinical or pre-clinical studies on a range of neuropsychiatric and neurological disorders. This journal is indexed on PubMed Central, the 'PsycINFO' database and CAS, and is the official

\section{Dovepress}

journal of The International Neuropsychiatric Association (INA). The manuscript management system is completely online and includes a very quick and fair peer-review system, which is all easy to use. Visit $\mathrm{http}: / /$ www.dovepress.com/testimonials.php to read real quotes from published authors. 